\title{
The interpretation of Spiritual Contemplation in the Modern Nichiren Sect
}

\author{
Hōyō WATANABE
}

\section{Kanjin-honzon-sho in which the Religion of Nichiren Is Clarified}

Rissho-ankoku-ron『立正安国論』is often regarded as symbolizing Nichiren's religion. It is probably because the presentation of Rissho-ankoku-ron by Nichiren to the important person of Kamakura shogunate is noted as an origin of his religious activities. We should point out that "Rissho-ankoku-ron" was written from the religious point of view and submitted as such.

However, it is in Kanjin-honzon-sho『锶心本尊抄』, written when he was 51 years old the religious world Nichiren had reached is revealed. (Kanjin-honzon-sho is the abbreviation of Nyorai-metsugo-gogohyakusaisi-kanjin-honzon-sho.) Nichiren`s purpose in writing Rissho-ankoku-ron was to remonstrate with the goverment, basing on the interpretation of the Lotus Sutra. Thereafter, he suffered from the continuaus persecution for 12 years. By accumulating his religious experience through the awareness persecution, his religious faith was raised. As a result he obtained the consciousness of being the practitioner of the Lotus Sutra.

When he was 32 years old, Nichiren came back from Mt. Hiei where he had been studying for many years to the Seicho-ji temple, and he reported the achievement of his studies and practices. As a result, he was expelled from the Seicho-ji Temple. Nichiren necessarily found a special meaning in his trip to Kamakura which was the capital of the Eastern Provinces in those days. The purpose of the trip was to realize his aspiration to save the people of the Age of Degenerated Law. Because, the cause of his expulsion from the Seicho-ji Temple was the doubt Nichiren had about the expansion of the Jodo sect. And Nichiren proposed that people should recover the proper meaning of the Lotus Sutra.

Initially, Nichiren didn`t have the ambition to submit Rissho-ankoku-ron. Nichi- 
The interpretation of Spiritual Contemplation in the Modern Nichiren Sect (H. WATANABE) ( 51 )

ren believed that the recovery of the Lotus Sutra was the requirement of the times. Then, he built a hermitage in Kamakura, and read Maka-shikan『摩訶止観』of Tendai (Chi-i, Grand Master T'ien-t'ai in China) with the people who had the same faith, and hoped for the regeneration of Buddhism by the Lotus Sutra. Historians pay attention to the activities of Nichiren in regard to Rissho-ankoku-ron. However, We should emphasize that the study of Maka-shikan he promoted existed in the background.

Through repeated persecution Nichiren became to have the awareness of being the practioner of the Lotus Sutra. He survived the crisis of life at Ryuko-honan (persecution), and he was banished to Sado Island. Luckily he was blessed with quiet environment in Sado Island, and proceeded with the study of Maka-shikan. Kanjinhonzon-sho was the result of his study there.

\section{Spiritual Contemplation in the Age of Degenerated Law}

What is Nichiren's point of view in writing Kanjin-honzon-sho and its conclusion? (1)Spiritual contemplation of the Lotus Sutra in the Age of Degenerated Law through chanting of the Daimoku. (2)The principal object of worship shown in the latter half 14 chapters of the Lotus Sutra is the stage of the eternal Buddha. (3)To confirm the spreading of the light of the relief of the Lotus Sutra. (I) "The Daimoku of the Honmon" (本門の題目), (II) “Honzon (the principal object of worship) of the Honmon” (本門の本尊), and (III) “the Kaidan(Precepts Platform) of the Honmon” (本門の戒壇) are called “Sandai-hiho" (three big secrets). And, it is some time after he wrote Kanjin-honzon-sho when he referred to the Three Big Secrets.

It is generally believed that "ichinen sanzen" (three thousand existence contained in one thought) was discessed in Maka-shikan to explain the way of meditation. The subtitle of Maka-shikan (Iwanami Bunko) of Shindai Sekiguchi (関口真大) is "Fundamental Principle of Zen." The book's title of Maka-shikan means the compilation of methods of meditation in the history of Buddhism. It explains the theory of "the concentration of thought and the observation of that thought." Because the theory of "ichinen sanzen" was clarified in Maka-shikan, the opinion insisting that the Lotus Sutra is a mere fable was denied. The Lotus Sutra received high regards after Tendai. We believe this is because the theory of "ichinen sanzen" became the basis of 
( 52 ) The interpretation of Spiritual Contemplation in the Modern Nichiren Sect (H. WATANABE)

the interpretation of the Lotus Sutra . A large number of of Maka-shikan have been published. These commentaries have had a great influence on the interpretation of the Lotus Sutra. This historical fact confirms with our contention.

Nichiren denied traditional opinions, and he didn't regard "ichinen sanzen" as the method of meditation. It is because Nichiren thought that the Lotus Sutra was the sacred sutra which predictes Buddha's relief of the people of the Age of Degenerted Law. Nichiren claims that it is the prediction of the Lotus Sutra.

This time, the Japanese association of Indian and Buddhist Studies organized a special meeting on "meditation". Dose the word of "samādhi" in the Lotus Sutra mean "meditation"? This issue was not discussed publicly. But, it is the doubt many scholars held.

3. The Interpretation of "Spiritual Contemplation" in Nichiren Buddhism in the Edo Period

Nichiren spread "the Lotus Sutra, a prediction" in the Kamakura Period. Thereafter, passing the Muromachi Period, Japan entered the age of Oda Nobunaga(織田 信長), Toyotomi Hideyoshi(豊臣秀吉), Tokugawa Ieyasu (徳川家康), the age of the unification of the country. Together with the other sects, Nichiren sect entered the age of persecution. It was prohibited to directly appeal to leading figures of the government. Furthermore, temples opposing against the shogunate policy was confiscated. Because external activities were restricted, introspective studies were promoted.

Nichigo (日護 1580-1649) practiced the meditation of the Lotus Sutra, limiting his belongings to the least, namely "three robes and an alms-bowl". It is said that activities of Nichiren priests changed after him. The priests engaged in meditation appeared and their activities were reported widely. However, a method of meditation was not established as practice of the Nichiren Sect, hampered by tradition.

Gensei (元政 1623-1668) served a Hikone feudal load in his younger days. After entering priesthood, he built a hermitage in Hukakusa in Kyoto, and he established a method of "practice to keep the precepts of the Lotus Sutra," and led a pure life. The theory of "ichinen sanzen" occupied the central part of his interpretation of the Lotus Sutra. He does not argue meditation as the method of the practice, though he 
expresses his comprehension in his poetry. Nitto (日透 1653-1717) is a rare person who belonged to various groups of the Nichiren Sect. He practiced meditation in a mountain in Aizu (present Fukushima Prefecture). It is said that he always muttered “things remain as they are.” Though he discusses “ji-no-ichinen-sanzen”(事一念三 千) in his Honmon-jino-Ichinenn-sanzen-gi, We feel that he does not argue meditation as the method of practice. Nichirin (日臨 1793-1823) accepted the assertion of Gensei. He treasured calmness and endurance. He is respected as a priest who observed precepts. He states in his Hokke-kanjin-san『法華観心賛』. “The objective honzon is that of honmon." "The subjective honzon in one's mind is that of the kanjin (spiritual concentration)." "The practice of spiritual contemplati on contemplation is aimed at realizing." "We are one with the Buddha."

Nichiki（日輝 1800-1859) is the person of conspicuousness. He opened "the Jugo-en," a private school in Kaga, Kanazawa (present Ishikawa Prefecture). He is reputed as a person who organized the doctrine of the modern Nichiren Sect. In those days, talented people of the Meiji Restoration were raised in private schools opened in various parts of the country. Similarly leaders of the Nichiren Sect after the Meiji Restoration were raised at “the Ju-go-en"(充洽園) of Nichiki. He wrote down the influence of the above mentioned Gensei and Nichirin. His assertion is termed as "the spiritual contemplation-Ju-go-en Zenshu (five volumes) contains his assertion. Nichiki's interpretation of "spiritual contemplation" is based on the interpretation of Nichirin and it is aimed at theorizing the interpretation. Teruji Ishizu (石津照濔) (the author of Tendai-jisso-ron 天台実相論) claims “Ichinen-sanzen-ron" of Nichiki is "a book difficult to understand." Nichiki denied "ichinen sanzen" of Tendai as "ri-no-ichinen-sanzen," noumienal and he admired the theory of "ji-no-Ichinen-sanzen" (factual) of Nichiren. Because this fundamental opinion can't be understood, it is evaluated as "the work that is difficult to understand."

\section{The Conclusion of Nichiren's Interpretation of "Ichinen Sanzen”}

We believe that the priests of the Nichiren Sect of in the Edo Period tried the application of "ichinen sanzen" through meditation in the closed religious environment. But, it can't be said that they succeeded in it. It is because Nichiren doesn't regard Maka-shikan of Tendai as "the principle of Zen practice." In this way, Nichi- 
( 54 ) The interpretation of Spiritual Contemplation in the Modern Nichiren Sect (H. WATANABE)

ren tried to clarify the principle of "ji-no-Ichinen-sanzen". He didn't make "Makashikan" as "the equation" of the meditation.

The word, "samādhi” (三昧) in the Lotus Sutra is said to mean "meditation"(瞋想) originally. But, We believe the word means the state Buddhas reached transcending the eternal time.

Nichiren thought that we could not reach the extremity of meditation in the Age of Degenerated Law (末法, the age when the Buddha dharma declines) by the function of one's mind. He denied meditation for this reason. Nichiren quoted "the source of ichinen sanzen" which appears in volume 5 of Maka-shikan in the beginning section of Kanjin-honzon-sho. He repeatedly examines in Kanjin-honzon-sho, "Can an ordinary person build Buddha's world in his mind?". He obtained the conclusion that "Buddha's world inheres in the own mind."

What should we do in making Buddha's world inhere in our own heart? A conclusion is shown in the sentence of “Shiju-go-ji hottai-dan”(四十五字法体段) of Kanjin-honzon-sho. It refers to "eternal practice by the Eternal Buddha, and "eternal relief." These are summarized in "our wish to embrace the Lotus Sutra." In other words, Buddha's "eternal practice" and "the reward which the Eternal Buddha attained" are summarized in the belief of "Namu-Myoho-Renge-Kyo" (南無妙法蓮華 経 the daimoku). The scholars of the Nichiren Sect of the Edo Period had difficulty in solving the problem of whether the theory of "ichinen sanzen" which Nichiren presented can be reproduced in the daily life.

〈Key Words〉 “Kanjin-honzon-sho," Ichinen Sanzen, meditation, Modern Nichiren sect (Professor Emeritus, Rissho University) 